\title{
PERKULIAHAN EKOLOGI DENGAN DIKTAT PADA MAHASISWA PENDIDIKAN GEOGRAFI FKIP UNIVERSITAS PGRI PALANGKA RAYA
}

\author{
DEDY NORSANDI \\ Dosen Program Studi Pendidikan Geografi Fakultas Keguruan dan Ilmu Pendidikan \\ Universitas PGRI Palangka Raya
}

\begin{abstract}
The purpose of this study are to knowing the teaching with dictat and the difficulties of it, properness of ecology dictat according to lectures and the opinion of college as a user, the result of study of college after using the dictat. To reach that purpose, the dictat tried to college and evaluation from lectures. The sample of this study are class A of 2012 colleger at first semester 2013/2014 who are programming ecology subjeck in geography education couses. Data was got by enquette and observation and than analysed by quantity description with distributed frequenty and table presentation.

The result of this study are the ecology dictat properly for teaching according to colleger, reviewer and lectures with the value is 4,1 (good category), and the study result of college on the average of 70,00 (good category), the opinion of collegers they feel happy using dictat as one of literature in their study. But there are some opinion that the dictat must be added with pictures and illustration to completing abstract material before publishing.
\end{abstract}

Keywords: lecturing, dictat

\section{ABSTRAK}

Tujuan penelitian ini adalah untuk mengetahui pelaksanaan pembelajaran dengan diktat dan hambatannya, mengetahui kelayakan diktat Ekologi menurut dosen serumpun dan tanggapan mahasiswa sebagai pengguna, serta mengetahui hasil belajar yang dicapai mahasiswa setelah menggunakan diktat tersebut. Untuk mencapai tujuan tersebut maka diktat diujicobakan kepada mahasiswa dan juga penilaian dari dosen serumpun. Sebagai sampel adalah mahasiswa S.1 2012 klas A yang pada semester ganjil 2013/2014 memprogram mata kuliah Ekologi di Program Studi Pendidikan Geografi. Data diperoleh dengan angket dan observasi kemudian dianalisis secara deskriptif kuantitatif dengan distribusi frekuensi dan persentase melalui tabulasi.

Hasil penelitian ini adalah diktat Ekologi sudah layak untuk digunakan baik menurut dosen serumpun, reviewer, maupun mahasiswa dengan nilai 4,1 (kategori baik), sedangkan hasil belajar mahasiswa rata-rata 70,00 (kategori baik), demikian pula tanggapan mahasiswa cukup menggembirakan yaitu senang dengan pembelajaran yang dilengkapi dengan sumber yang jelas yaitu diktat. Namun demikian masih ada juga komentar yang sebagian besar mengharapkan sebelum diterbitkan sebagai diktat masih perlu ditambahkan gambar-gambar dan ilustrasi guna melengkapi materi yang masih bersifat abstrak.

Kata kunci: perkuliahan, diktat

\section{PENDAHULUAN}

Berbagai upaya telah ditempuh oleh Universitas PGRI Palangka Raya dalam rangka meningkatkan kualitas lulusannya. Salah satu diantaranya adalah melalui peningkatan proses belajar mengajar (PBM). Peningkatan PBM ini dikembangkan melalui : 1) pemantapan kualitas perkuliahan, 2) pengoptimalan sarana dan prasarana perkuliahan, 3) pola perumpunan mata kuliah, 4) pemantapan kegiatan peningkatan kualitas PBM misalnya rekonstruksi kuliah, paket belajar, 5) kegiatan penelitian yang berkaitan langsung dengan kualitas perkuliahan, 6) pengadaan sarana belajar dan bahan ajar, 
7) pemantapan perpustakaan, 8) pengembangan dan pemanfaatan pusat sumber belajar (PSB), dan 9) pemberian prioritas tinggi pada sarana belajar (Anonim, 2010). Upaya tersebut memberikan hasil yang positif misalnya indeks prestasi kumulatif (IPK) mahasiswa terus meningkat, termasuk efisiensi edukasi juga meningkat.

Keberhasilan perkuliahan sebenarnya bukan semata-mata terletak pada aktivitas dan kemampuan dosen dalam memberikan ceramah, melainkan lebih bergantung pada aktivitas belajar mahasiswa dalam perkuliahan tersebut. Aktivitas belajar mahasiswa dalam perkuliahan itulah yang lebih menentukan efektifitas perkuliahan yang bersangkutan. Oleh karena itu dalam suatu perkuliahan semua komponen yang terlibat hendaknya diarahkan untuk meningkatkan aktivitas belajar mahasiswa. Peran dosen yang utama adalah menyediakan bahan ajar, alat dan mengatur situasi agar lebih mendorong aktivitas mahasiswa untuk belajar. Penyediaan bahan ajar terutama berupa diktat masih dirasakan sangat kurang oleh mahasiswa. Apalagi dalam kenyataannya banyak dosen khususnya di Program Studi Pendidikan Geografi FKIP Universitas PGRI Palangka Raya masih menggunakan metode ceramah klasikal. Padahal apabila dilihat dari pendekatan PBM dengan penerapan diktat akan dapat menambah kadar cara belajar mahasiswa aktif (CBMA) dan meningkatkan penalaran mahasiswa.

Dalam era informasi memang sumber belajar tidak terbatas pada buku atau diktat saja, dapat pula sumber belajar diperoleh dari internet. Namun demikian, penggunaan diktat dalam perkuliahan Ekologi dianggap memberikan urunan unik bagi perbaikan PBM karena dapat meningkatkan derajat penstrukturan pengalaman belajar mengajar yang terlihat dalam aktualisasi kegiatan belajar mengajar.

Melihat berbagai upaya Universitas PGRI Palangka Raya tersebut di atas, maka peneliti berkeinginan untuk melaksanakan dan menerapkan kepada mahasiswa Program Studi Pendidikan Geografi FKIP Universitas PGRI Palangka Raya dalam rangka PBM Ekologi dengan menggunakan diktat. Hal ini dilakukan dengan harapan kualitas perkuliahan Ekologi lebih meningkat sekaligus meningkatkan kualitas lulusan.

Tujuan penelitian ini adalah: 1) ingin mengidentifikasi pelaksanaan perkuliahan dengan diktat beserta hambatan-hambatan yang dihadapi, 2) ingin mengetahui kelayakan diktat yang telah disusun oleh dosen berdasarkan penilaian reviewer, 3) ingin rnendeskripsikan tanggapan mahasiswa terhadap perkuliahan Ekologi dengan menggunakan diktat, 4) ingin mengetahui hasil belajar dalam perkuliahan Ekologi dengan menggunakan diktat.

\section{METODOLOGI}

Penelitian ini dilaksanakan pada bulan September 2013 - Januari 2014. Penelitian ini dilakukan di Universitas PGRI Palangka Raya Jalan Hiu Putih Palangka Raya.

Populasi dalam penelitian ini adalah seluruh mahasiswa S.I Angkatan 2012 Pendidikan Geografi yang pada semester ganjil 2013/2014 memprogram mata kuliah Ekologi yang berjumlah 85 mahasiswa. Karakteristik klas A sebagian hasil SPMB dan sebagian program non-reguler, sedangkan di klas B didominasi oleh mahasiswa 
hasil seleksi tes SPMB. Oleh karena itu, sampel penelitian diambil dari klas $\mathrm{A}$ yang berjumlah 45 mahasiswa dimana kondisinya sudah relatif hiterogen. Untuk menentukan responden digunakan cara random-sampling dengan sistem lotere.

Sesuai dengan rumusan masalah, variabel penelitian ini adalah:

a. Pelaksanaan dan hambatan-hambatan yang dihadapi dalam perkuliahan Ekologi dengan diktat.

b. Penilaian reviewer terhadap kelayakan diktat yang terdiri dari:
1) Segi isi.
2) Penggunaan media.
3) Evaluasi meliputi: prosedur, jenis dan alat evaluasi
4) Kesesuaian materi dengan evaluasi.

c. Tanggapan mahasiswa terhadap pelaksanaan penerapan diktat, meliputi:
1) Pelaksanaan orientasi
2) Pelaksanaan latihan
3) Pelaksanaan pemberian umpan balik
4) Pelaksanaan penggunaan media belajar
5) Pelaksanaan penilaian hasil belajar

d. Hasil belajar mahasiswa dalam mata kuliah Ekologi dengan diktat yang diuji cobakan. Dimana nilai mahasiswa yang diperoleh dalam uji coba ini dimasukkan dalam nilai tugas, tengah semester dan akhir semester.

Teknik pengumpulan data dilakukan berupa: a) angket digunakan untuk pengumpulan data yang berkaitan dengan variabel tanggapan mahasiswa dan dosen untuk kelayakan diktat, serta tanggapan mahasiswa terhadap penerapan diktat, b) tes hasil belajar digunakan untuk memperoleh data mengenai prestasi belajar mahasiswa dengan menggunakan diktat, c) observasi digunakan untuk mengadakan pengamatan secara umum mengenai suasana perkuliahan yang dilaksanakan dengan diktat.

Prosedur penelitian, meliputi: a) menyusun diktat, b) melaksanakan perkuliahan dengan diktat, c) mengumpulkan data penelitian, d) menyusun laporan penelitian.

Data kuantitatif dianalisis dengan deskriptif kuantitatif, sedangkan data kualitatif dianalisis dengan deskriptif kualitatif berdasarkan teori yang ada dan logis. Deskriptif kuantitatif digunakan untuk mencari rata-rata dari penilaian terhadap kelayakan diktat dengan menggunakan skala angka sebagai berikut:
a. Angka 1 berarti kurang sekali.
b. Angka 2 berarti kurang.
c. Angka 3 berarti cukup.
d. Angka 4 berarti baik.
e. Angka 5 berarti baik sekali.

Sedangkan prosentase digunakan untuk analisis tanggapan mahasiswa dalam perkuliahan dengan diktat. Adapun untuk hasil belajar mahasiswa digunakan nilai angka apa adanya yaitu 0 sampai 100 .

\section{HASIL DAN PEMBAHASAN}

\section{Hasil Penelitian}

\section{a. Kelayakan Diktat}

Kelayakan diktat didasarkan pada hasil angket yang diberikan kepada dosen serumpun sebagai reviewer dan penilaian dari mahasiswa. Angket untuk dosen dan mahasiswa berbeda. Untuk dosen seluruh komponen paket diminta untuk mengadakan penilaian mulai dari isi diktat, cara penyampaian dan bentuk fisik diktat. Sedangkan untuk mahasiswa terbatas penekanan 
kepada bentuk fisik diktat, cara penyampaian dan media penunjang yang dipakai. Hal ini didasarkan pada pertimbangan bahwa mahasiswa belum kompeten dalam hal menilai diktat secara keseluruhan. Hasil angket yang diberikan kepada dosen dan mahasiswa dapat diperhatikan pada Tabel 1 dan Tabel 2.

Berdasarkan Tabel 1 dan Tabel 2, jumlah frekuensi jawaban dikalikan dengan rentangan angka yang sudah ditetapkan, maka diperoleh sejumlah angka jawaban yang kemudian dicari rata-ratanya. Secara keseluruhan dari hasil angket dari dosen dan mahasiswa diperoleh angka rata-rata 4,1 dan 4,16 . Jika angka rata-rata tersebut dilihat dari keseluruhan termasuk kriteria baik, sehingga diktat yang digunakan dalam pembelajaran mata kuliah Ekologi dapat dikatakan layak.

Jika dirinci lebih jauh lagi, dari masingmasing komponen yang terdapat di dalamnya dapat dijelaskan berdasarkan masing-masing penilaian, baik dari dosen maupun dari mahasiswa.

\section{1) Penilaian dan Tanggapan Dosen}

a. Rasional diktat, yaitu pengungkapan ciri khas diktat dinyatakan jelas, karena kemampuan memotivasi mahasiswa cukup jelas dengan nilai rata-rata 4,1 sehingga termasuk baik.

b. Tujuan, yaitu kemampuan yang dikandung dalam kompetensi sudah komprehensif, penjabaran kompetensi menjadi indikator baik sekali dan sudah tepat. Jumlah indikator dengan waktu sudah memadai, kemampuan yang terkadung dalam keseluruhan indikator juga komprehensif. Rumusan indikator jelas dan spesifik dengan nilai rata-rata 4,7 yang berarti termasuk baik. c. Materi yang disajikan, yaitu isi diktat sesuai dengan perkembangan bidang studi, pengorganisasian dan sistematik sudah variatif, luasnya sudah memadai, tingkat kesukaran sesuai dengan perkembangan manusia, manfaat bagi mahasiswa sangat besar dan dapat mendorong mahasiswa kritis juga besar. Nilai rata-rata tentang materi yang disajikan mencapai 4,3 yang berarti kategori baik.

d. Bahasa, yaitu pemilihan istilah dalam diktat sudah tepat, penggunaan bahasa baku sudah baik, tingkat kesukaran bahasa sesuai dengan tingkat penguasaan bahasa untuk mahasiswa, gaya bahasa yang digunakan cukup menarik sehingga rata-rata nilainya 4,3 berarti kategori baik.

e. Media, yaitu media yang digunakan dalam perkuliahan dilihat dari jenisnya sudah sesuai dengan tujuan dan materi yang disajikan. Hanya saja variasi penggunaan alat terlalu sedikit (hanya OHP) sehingga perlu dikembangkan lagi. Nilai rata-rata mencapai 3,7 yang berarti kategori baik.

f. Sumber yang dipakai dalam diktat, yaitu relevansi buku-buku yang dipakai dalam menyusun diktat sudah relevan dengan tujuan dan memadai. Hal tersebut diketahui dari nilai rata-rata mencapai 4,2 yang berarti kategori baik.

g. Evaluasi, yaitu dalam diktat termasuk baik dengan nilai rata-rata mencapai 3,94 dimana prosedur evaluasi sudah relevan dengan tujuan dan kriteria pencapaian keberhasilan termasuk sangat baik. 
Tabel 1. Hasil angket penilaian dosen terhadap diktat

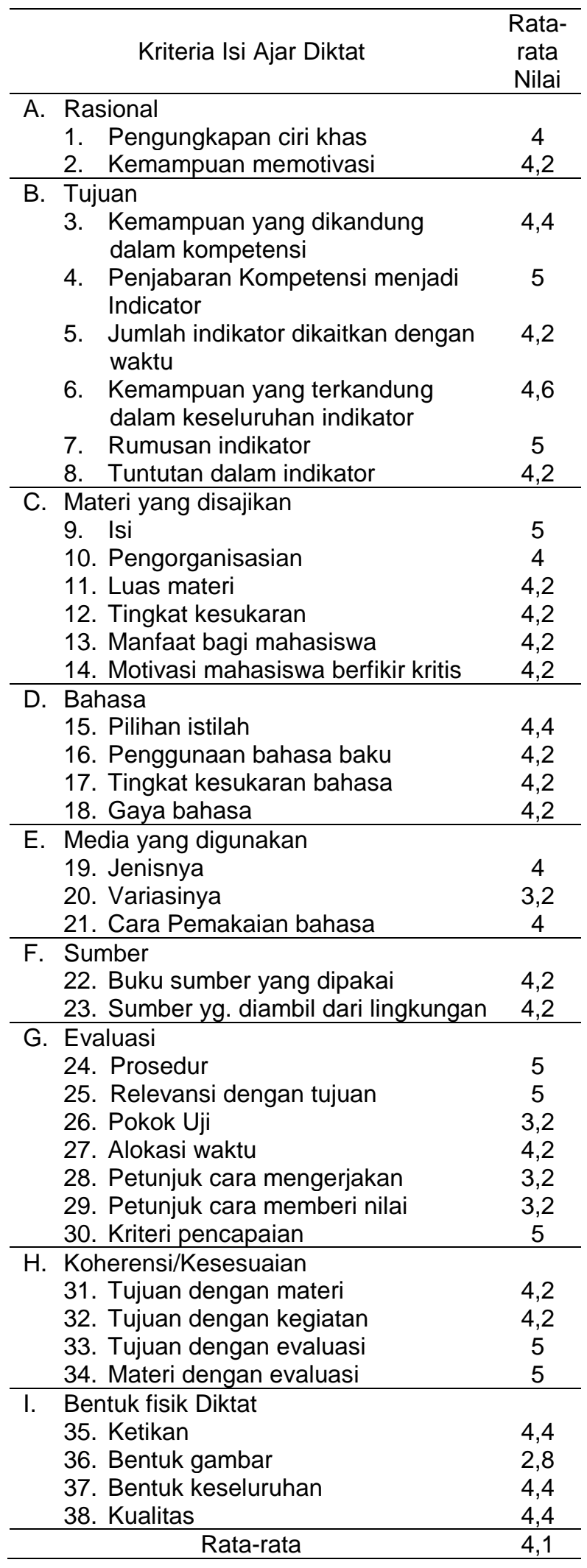

Tabel 2. Hasil angket penilaian diktat oleh mahasiswa

\begin{tabular}{llc}
\hline \multicolumn{1}{c}{ Kriteria Diktat } & $\begin{array}{c}\text { Rata- } \\
\text { rata } \\
\text { Nilai }\end{array}$ \\
\hline A. Bentuk fisik Diktat & \\
1. Ketikan & 4 \\
2. Bentuk gambar & 4 \\
3. Bentuk keseluruhan & 3,9 \\
4. Kualitas bahan & 3,9 \\
\hline B. Cara penyampaian Diktat & 4 \\
5. Strategi yang digunakan & 4,2 \\
6. Kegiatan yang disajikan & 4 \\
7. Orientasi kegiatan & 4,8 \\
8. Alternatif kegiatan & 4,9 \\
9. Urutan Kegiatan & 4,3 \\
\hline C. Media yang digunakan & 3,6 \\
10. Jenisnya & 4,2 \\
11. Variasinya & 4,16 \\
\hline 12. Cara pemakaian & \multicolumn{2}{c}{ Rata-rata }
\end{tabular}

h. Koherensi/kesesuaian, yaitu dapat ditinjau dari koherensi tujuan dengan materi, tujuan dengan kegiatan, tujuan dengan evaluasi, materi dengan evaluasi secara keseluruhan nilai rata-ratanya mencapai 4,6 sehingga termasuk kategori baik.

i. Cara penyampaian diktat, yaitu diktat menggunakan strategi yang bervariasi, kegiatan yang disajikan dikatakan menarik dan mudah diikuti oleh mahasiswa. Pada umumnya orientasi kegiatan berfokus kepada mahasiswa, alternatif kegiatan yang disajikan serta adanya kegiatan individual dan kegiatan kelompok. Selaian itu urutan kegiatan juga bervariasi. Nilai rata-ratanya mencapai 4,6 sehingga komponen cara penyampaian diktat kepada mahasiswa tergolong baik.

j. Bentuk fisik diktat, yaitu secara keseluruhan bentuk fisik diktat tergolong baik, karena nilai rata-ratanya mencapai 4 . Bentuk keseluruhan dari diktat dikatakan menarik dan kualitas bahan baik. Rata-rata hasil penilaian seluruh 
komponen bentuk diktat adalah 4,1 yang dapat dikatakan bahwa diktat Ekologi menurut dosen serumpun adalah baik atau layak digunakan untuk mahasiswa.

\section{2) Penilaian Diktat oleh Mahasiswa}

Bentuk fisik diktat menurut mahasiswa, secara keseluruhan tergolong baik dengan nilai rata-rata 3,05. Komponen ketikan artikel baik dan jelas, bentuk gambar sudah jelas dan kualitas bahan sudah baik.

Cara penyampaian diktat menggunakan strategi yang bervariasi, kegiatan yang disajikan menarik dan mudah diikuti. Orientasi kegiatan berfokus pada mahasiswa, alternatif kegiatan yang disediakan setara, karena ada kegiatan individual maupun kegiatan kelompok. Urutan kegiatan juga variatif. Nilai rata-rata 4,38 yang berarti dikategorikan baik.

Tentang media yang dipakai dalam perkuliahan, secara umum dikatakan bahwa jenisnya sesuai dengan tuntutan dari materi dan variasinya tergolong baik, yaitu nilai rata-ratanya 4,1 yang termasuk kategori media yang dipakai baik. Sedangkan rata-rata hasil penilaian seluruh komponen dari mahasiswa adalah 4,16 sehingga diktat yang diujicobakan menurut pendapat mahasiswa dikategorikan baik.

\section{b. Hasil Belajar Mahasiswa}

Diktat ini diujicobakan kepada mahasiswa S.1 Angkatan 2012 Kelas A sebanyak 45 mahasiswa. Adapun hasil belajar mahasiswa setelah mengikuti kegiatan perkuliahan dapat diperhatikan pada Tabel 3.
Tabel 3. Hasil belajar mahasiswa di akhir perkuliahan

\begin{tabular}{|c|c|c|}
\hline No. & Nomor Pokok Mahasiswa & Nilai \\
\hline 1. & 1287202001 & 70 \\
\hline 2. & 1287202002 & 75 \\
\hline 3. & 1287202003 & 70 \\
\hline 4. & 1287202004 & 70 \\
\hline 5. & 1287202005 & 75 \\
\hline 6. & 1287202006 & 70 \\
\hline 7. & 1287202007 & 70 \\
\hline 8. & 1287202008 & 70 \\
\hline 9. & 1287202009 & 70 \\
\hline 10. & 1287202010 & 65 \\
\hline 11. & 1287202011 & 70 \\
\hline 12. & 1287202012 & 78 \\
\hline 13. & 1287202013 & 70 \\
\hline 14. & 1287202014 & 75 \\
\hline 15. & 1287202015 & 75 \\
\hline 16. & 1287202016 & 70 \\
\hline 17. & 1287202017 & 75 \\
\hline 18. & 1287202018 & 70 \\
\hline 19. & 1287202019 & 70 \\
\hline 20. & 1287202020 & 70 \\
\hline 21. & 1287202021 & 75 \\
\hline 22. & 1287202022 & 80 \\
\hline 23. & 1287202023 & 70 \\
\hline 24. & 1287202024 & 70 \\
\hline 25. & 1287202025 & 70 \\
\hline 26. & 1287202026 & 70 \\
\hline 27. & 1287202027 & 70 \\
\hline 28. & 1287202028 & 75 \\
\hline 29. & 1287202029 & 70 \\
\hline 30. & 1287202030 & 70 \\
\hline 31. & 1287202031 & 70 \\
\hline 32. & 1287202032 & 70 \\
\hline 33. & 1287202033 & 70 \\
\hline 34. & 1287202034 & 70 \\
\hline 35. & 1287202035 & 70 \\
\hline 36. & 1287202036 & 78 \\
\hline 37. & 1287202037 & 65 \\
\hline 38. & 1287202038 & 70 \\
\hline 39. & 1287202039 & 70 \\
\hline 40. & 1287202040 & 80 \\
\hline 41. & 1287202041 & 75 \\
\hline 42. & 1287202042 & 70 \\
\hline 43. & 1287202043 & 80 \\
\hline 44. & 1287202044 & 70 \\
\hline \multirow[t]{2}{*}{45.} & 1287202045 & 80 \\
\hline & Rata-rata & 71,9 \\
\hline
\end{tabular}


Berdasarkan hasil tes tersebut, rata-rata nilai yang diperoleh mahasiswa adalah 71,9 yang berarti termasuk kategori baik. Berdasarkan Tabel 3 apabila nilai yang diperoleh mahasiswa dapat dirinci lagi adalah sebagai berikut:

a. Nilai $\leq 65$ sejumlah 2 mahasiswa atau $4,45 \%$

b. Nilai 66-79 sejumlah 39 mahasiswa atau $86,66 \%$

c. Nilai $\geq 80$ sejumlah 4 mahasiswa atau $8,89 \%$

Dari rincian tersebut $\mathrm{di}$ atas dapat disimpulkan bahwa sebagian besar $86,66 \%$ mahasiswa mendapat nilai 66-79 yang berarti termasuk kategori baik.

\section{c. Tanggapan Mahasiswa terhadap Pelaksanaan PBM dengan Diktat}

Setelah dilakukan perkuliahan dengan
diktat, kemudian mahasiswa diminta
tanggapannya terhadap pelaksanaan perkuliahan. Hasil angket yang diperoleh dari sejumlah 45 mahasiswa peserta perkuliahan, yang menyatakan senang 100\%. Alasan mereka senang mengikuti perkuliahan dengan diktat sangat bervariasi seperti pada Tabel 4 .

Tabel 4. Variasi jawaban mahasiswa senang mengikuti perkuliahan dengan diktat

\begin{tabular}{clcc}
\hline No. & \multicolumn{1}{c}{ Aspek Alasan } & f & $\%$ \\
\hline 1. & a. b. c. d. e. f. g. & 12 & 26,7 \\
2. & c. f. g. & 6 & 13,3 \\
3. & c. g. & 3 & 6,7 \\
4. & a. b. d. & 6 & 13,3 \\
5. & a. b. c. d. e. f. g. & 3 & 6,7 \\
6. a. b. c. d. & 3 & 6,7 \\
7. & a. c. d. f. & 5 & 11,2 \\
8. & a. c. d. g. & 2 & 4,4 \\
9. & a. c. d. f. g. & 1 & 2,2 \\
10. & a. d. g. d. g. & 1 & 2,2 \\
11. & a. b. c. d. g. & 2 & 4,4 \\
12. a. c. d. f. g. & 1 & 2,2 \\
\hline \multicolumn{4}{c}{ Jumlah } \\
\hline
\end{tabular}

Keterangan :

$\mathrm{a}=$ Diktat menerapkan langkah-langkah kegiatan belajar yang memudahkan penguasaan materi

$\mathrm{b}=$ Tidak membosankan

$\mathrm{c}=$ Merangsang minat belajar

$\mathrm{d}=$ Memberikan petunjuk yang jelas dalam kegiatan belajar

e = Menyediakan bahan yang lengkap yang diperlukan untuk kegiatan

$f=$ Menyediakan alternatif kegiatan individual dan kegiatan kelompok

$\mathrm{g}$ = Dalam mengikuti perkuliahan, mahasiswa jauh lebih siap, karena pokok bahasan artikelnya sudah disiapkan terlebih dulu

Berdasarkan Tabel 4 menunjukkan bahwa sebagian besar mahasiswa (26,7\%) senang mengikuti perkuliahan dengan diktat karena menerapkan langkah-langkah kegiatan belajar yang memudahkan penguasaan materi, tidak membosankan, merangsang minat belajar, dilaksanakan dengan kegiatan individu maupun kelompok, serta mendorong mahasiswa lebih siap karena artikel dalam diktat sudah diberikan sebelum perkuliahan dimulai.

Seluruh mahasiswa menyatakan bahwa setiap penggalan bab diberikan latihan dan tes manfaatnya sangat besar (100\%). manfaatnya menurut mereka ada dua variasi, yaitu 32 mahasiswa atau $71,87 \%$ menyatakan bahwa manfaatnya adalah memperdalam materi, meningkatkan aktivitas belajar dan mengenal berbagai macam soal sebagai persiapan menghadapi ujian akhir semester. Sedangkan 13 mahasiswa atau $28,13 \%$ menyatakan adanya soal latihan dalam penggalan bab ke bab yang lain hanya memperjelas penyajian materi saja. Selanjutnya mengenai umpan balik mencocokkan hasil latihan bahwa 42 mahasiswa (93,75\%) menyatakan sangat besar manfaatnya dan 3 mahasiswa $(6,25 \%)$ tidak memberikan jawaban. 


\section{Pembahasan}

Temuan dalam uji coba diktat ini mencakup dua hal, yaitu kelebihan dan kekurangan diktat yang disusun. Kelebihan diktat menunjukkan bahwa:

a. Perkuliahan dengan diktat mendorong mahasiswa lebih aktif dan percaya pada kemampuan diri sendiri.

b. Mahasiswa lebih responsif. Hal ini dibuktikan dengan adanya jumlah kenaikan mahasiswa yang mengajukan berbagai macam pertanyaan di setiap bab yang dibahas.

c. Hasil kegiatan belajar mengajar dengan diktat setelah mengikuti tes seluruh kegiatan Bab I sampai dengan Bab XVI nilai rata-ratanya mencapai 71,9 .

d. Seluruh mahasiswa peserta mata kuliah Ekologi sejumlah 45 mahasiswa (100\%) menyatakan senang mengikuti perkuliahan dengan menggunakan diktat.

e. Alasan mereka menyatakan senang sangat bervariasi, tetapi yang terbesar (26,7\%) menyatakan bahwa adanya diktat memudahkan penguasaan materi, tidak membosankan, merangsang minat belajar, dan mendorong mahasiswa lebih siap setiap pertemuan.

f. Sebagai besar mahasiswa $(71,87 \%)$ menyatakan manfaatnya sangat besar bila tiap akhir bab diadakan latihan. Manfaatnya adalah memperdalam penguasaan materi, meningkatkan aktivitas belajar dan mengenal berbagai macam soal sebagai persiapan menghadapi ujian. g. Kegiatan umpan balik untuk mencocokkan hasil latihan, mahasiswa menyatakan sangat besar manfaatnya (93,75\%). Adapun manfaatnya adalah dapat mengetahui jawaban soal-soal latihan yang benar dan yang salah, serta memperdalam penguasaan materi.

h. Mahasiswa lebih tekun dan sangat respon di dalam kegiatan belajar mengajar.

Sedangkan kekurangan diktat yaitu :

a. Tentang media yang dipakai dalam menunjang diktat kurang variatif, sehingga kurang memberikan daya tarik. Terutama masih menggunakan OHP,

b. Alokasi waktu untuk mengerjakan soal latihan kurang memadai.

\section{KESIMPULAN DAN SARAN}

Kesimpulan

Berdasarkan hasil uji coba pelaksanaan perkuliahan dengan diktat dalam mata kuliah Ekologi dapat ditarik kesimpulan:

1. Rata-rata penilaian dari dosen terhadap kelayakan diktat Ekologi adalah 4,1 dimana dapat dikatakan baik.

2. Rata-rata penilaian dari mahasiwa terhadap diktat Ekologi adalah 4,16 juga dapat dikatakan baik.

3. Rata-rata hasil belajar mahasiswa setelah menggunakan diktat adalah 71,90 dengan demikian termasuk kategori baik.

4. Secara keseluruhan pelaksanaan perkuliahan dengan diktat mendapat tanggapan yang baik dan merasa senang. 


\section{Saran}

Berdasarkan kesimpulan, maka dapat dikemukakan saran-saran sebagai berikut:

1. Karena pelaksanaan perkuliahan pada mata kuliah Ekologi dengan menggunakan diktat hasilnya baik, seyogyanya cara seperti ini juga diikuti oleh mata kuliah yang belum pernah menggunakan diktat dalam proses belajar mengajar.

2. Karena hasil uji coba diktat dalam mata kuliah Ekologi cukup banyak mahasiswa yang berhasil baik, maka sebaiknya perkuliahan dengan diktat di Program Studi Pendidikan Geografi FKIP Universitas PGRI Palangka Raya dikembangkan.

3. Karena perkuliahan dengan diktat memerlukan sarana serta biaya, maka sebaiknya pihak lembaga dalam hal ini fakultas dan universitas menyediakan dana untuk pelaksanaannya.

\section{DAFTAR PUSTAKA}

Anonim. 2010. Renstra Universitas PGRI Palangka Raya. Universitas PGRI Palangka Raya. Palangka Raya.

Arikunto, S. 2010. Prosedur Penelitian: Suatu Pendekatan Praktik. Rineka Cipta. Jakarta.

Aunurrahman. 2010. Belajar dan Pembelajaran. Alfabeta. Bandung.

Enoh, Moch. 2005. Petunjuk Penulisan Buku Ajar, Buku kerja Lokakarya Penulisan Buku Ajar dan Petunjuk Praktikum, SP4 Jurusan Pendidikan Geografi FIS-UNESA. Universitas Negeri Semarang.

Moh. Pabundu Tika. 2005. Metode Penelitian Geografi. Bumi Aksara. Jakarta.
Slameto. 2010. Belajar dan Faktor-faktor yang Mempengaruhinya. Rhineka Cipta. Jakarta.

Sumaatmadja, 1981, Studi Geografi Suatu Pendekatan dan Analisa Keruangan. Alumni. Bandung.

Wawan, Dewi. 2010. Teori dan Pengukuran Pengetahuan, Sikap, dan Perilaku Manusia. Nuha Medika. Yogyakarta. 